\title{
Are surgeons ethically obligated to treat Medicare patients despite substantial reductions in reimbursement? Introduction
}

Robert M. Sade, MD

See related articles by Edward D. Verrier on pp 38-40 and Tea E. Acuff on pp 41-3.

The US Congress created Medicare in 1964 as a means to provide financial coverage of health care costs to US citizens over the age of 65 years. The ensuing rapid growth of health care costs induced the federal program to search for ways to control the disproportionately high rate of cost increase, and reimbursement of physicians' charges for services rendered became a prime target of cost control. According to the Congressional Budget Office, ${ }^{1}$ between 1972 (8 years after their creation) and 2011, federal spending on Medicaid and Medicare rose 5 -fold from $1.1 \%$ of the gross domestic product to $5.5 \%$ in 2011 and is projected to rise to at least $8.4 \%$ by 2030 and to $10 \%$ by 2037 .

It seems likely that cardiothoracic surgeons will be particularly hard hit by the cost-saving measures that the Centers for Medicare and Medicaid Services will almost certainly impose in the next few years, because current trends are likely to continue. For example, reimbursement for coronary artery bypass grafting fell from $\$ 3957$ in 1989 to $\$ 2049(48 \%)$ in $2006 .^{2}$ Moreover, the Affordable Care Act cuts $\$ 716$ billion from Medicare over the next 10 years, and it does not take much imagination to guess that a good deal of that sum will come from physicians' reimbursements through the "sustainable growth rate" mechanism. ${ }^{3}$

As reimbursement declines, the margin between practice overhead costs and revenue will decrease. Some physicians already have stopped accepting new Medicare patients into their practices, and as financial pressure increases, those

From the Division of Cardiothoracic Surgery, Department of Surgery, and the Institute of Human Values in Health Care, Medical University of South Carolina, Charleston, SC.

Dr Sade's role in this publication was supported by the South Carolina Clinical \& Translational Research Institute, Medical University of South Carolina's Clinical and Translational Science Award Number UL1RR029882. The contents are solely the responsibility of the authors and do not necessarily represent the official views of the National Center For Research Resources or the National Institutes of Health. Disclosures: Author has nothing to disclose with regard to commercial support.

Read at the 92nd Annual Meeting of The American Association for Thoracic Surgery, San Francisco, California, April 28-May 2, 2012.

Received for publication Sept 13, 2012; accepted for publication Sept 24, 2012; available ahead of print Oct 24, 2012.

Address for reprints: Robert M. Sade, MD, Department of Surgery, Medical University of South Carolina, 25 Courtenay Dr, Suite 7028, MSC 295, Charleston, SC 29425 (E-mail: sader@musc.edu).

J Thorac Cardiovasc Surg 2013;145:37

$0022-5223 / \$ 36.00$

Copyright (c) 2013 by The American Association for Thoracic Surgery

http://dx.doi.org/10.1016/j.jtcvs.2012.09.067 numbers are likely to increase. Is there a point at which cardiothoracic surgeons would be justified in refusing to accept new Medicare patients?

An ethical obligation to care for Medicare patients is implied by the American Medical Association Code of Medical Ethics, ${ }^{4}$ which states: "A physician shall, while caring for a patient, regard responsibility to the patient as paramount." Our own American Association for Thoracic Surgery Code of Ethics ${ }^{5}$ echoes this principle: "When caring for patients, members must hold the patient's welfare paramount."

The American Medical Association Code of Medical Ethics ${ }^{4}$ also provides support for the alternative view that there is no obligation to provide care: "A physician shall, in the provision of appropriate patient care, except in emergencies, be free to choose whom to serve, with whom to associate, and the environment in which to provide medical care."

At the 2012 Annual Meeting of The American Association Thoracic Surgery, the Ethics Forum sponsored a debate on the question of whether surgeons are ethically obligated to treat Medicare patients even when facing substantial reductions in reimbursement. Edward Verrier argued the proponent's view and Tea Acuff the contrary view. Their discussion focused on a brief vignette that describes a situation typical of many cardiothoracic surgeons.

\section{THE CASE OF THE FINANCIALLY SQUEEZED SURGEON}

Dr Henry Jones has a large practice in cardiothoracic surgery, with $30 \%$ to $40 \%$ Medicare patients. During the past several years, diminishing compensation for cardiac surgical procedures and need for additional staff to deal with increasing regulatory requirements have sharply reduced his income, and further reductions in Centers for Medicare and Medicaid Services compensation levels are scheduled to be implemented soon. He wonders whether he has to continue to accept Medicare patients despite substantial reductions in reimbursement.

\section{References}

1. Congressional Budget Office, Congress of the United States. The 2012 long-term budget outlook. Available at: http:/www.cbo.gov/sites/default/files/cbofiles/ attachments/06-05-Long-Term_Budget_Outlook.pdf. Accessed August 24, 2012.

2. Peck B. Trends in Medicare reimbursement. Bull Am Coll Surg. 2006;91:8-12.

3. Elmendorf DW. Letter to the Honorable John Boehner. Congressional Budget Office, July 24, 2012. Available at: http://www.cbo.gov/sites/default/files/ cbofiles/attachments/43471-hr6079.pdf. Accessed September 5, 2012.

4. Council on Ethical and Judicial Affairs. Principles of medical ethics. In: Code of medical ethics, 2012-2013. Chicago: American Medical Association; 2012:xv.

5. Code of ethics. American Association for Thoracic Surgery. Available at: http:// aats.org/association/policies/Code_of_Ethics.cgi. Accessed August 24, 2012. 